\title{
AVKOBLING OG TRANSFORMASJON MeditasjonsRetreater PÅ Dharma Mountain Mellom POPULARISERING OG RELIGIØST FELLESSKAP
}

\author{
Henriette Hanky \\ Universitetet i Bergen \\ henriette.hanky@uib.no
}

\begin{abstract}
While meditation has undeniably become a part of popular culture, the term encompasses a wide variety of practices and conceptualizations on the religious-secular spectrum. In this paper, I explore how this wide scope is dealt with at meditation retreats offered at the Norwegian center Dharma Mountain. The place is built around the Norwegian guru Vasant Swaha and serves as a meeting place for his disciples, the sangha. At the same time, the Dharma Mountain group takes part in the wider popular meditation field with retreats tailored toward the preferences of an often guru-critical mainstream audience. Based on ethnographical material, I compare two meditation techniques, vipassana and Dynamic Meditation, and how they are introduced, legitimized, and performed at a newcomer weekend in the first and a summer retreat with Vasant Swaha in the second case. I show that while instructors introduce vipassana as a generic and simple technique, they mark Dynamic Meditation as a specifically composed method and thus integrate it with Swaha's background in the Osho movement and the therapeutic outlook of his retreats. My findings point to the flexibility of the concept of meditation and how this helps organizers to address different audiences. Under the umbrella of meditation, Dharma Mountain incorporates a range of conceptualizations, from self-help to spiritual awakening, and different social forms, from costumer relations to religious community, in one and the same place.
\end{abstract}

\author{
NøKKELORD \\ Meditation - Retreat tourism - Popular religion - Osho (Bhagwan Shree \\ Rajneesh) - Vipassana - Dynamic Meditation - Satsang
}




\section{INNLEDNING}

Meditasjon er et paraplybegrep som omfatter et vidt spekter teknikker og konseptualiseringer-fra det religiøse til det sekulære og fra populærkultur til spesialkunnskap. I denne artikkelen undersøker jeg hvordan arrangørene på det norske retreat-senteret Dharma Mountain i Valdres forholder seg til denne spennvidden på meditasjonsretreatene de tilbyr. Senterets kjerneaktivitet er retreater med den norske guruen og Osho-disippelen Vasant Swaha, som nå selv tiltrekker disipler fra ulike deler av verden. De siste årene har senteret også begynt å tilby kortere retreater uten guruen. Disse appellerer til et bredere publikum med interesse for meditasjon og yoga. Senteret er dermed et krysningspunkt som tar del i en popularisert diskurs rundt meditasjon og mindfulness og bringer samtidig sammen et dedikert religiøst fellesskap — sanghaen. I det følgende skal jeg undersøke hvordan tilstedeværelsen av disse forskjellige sosiale formene preger hvordan meditasjon formidles, legitimeres og utøves på retreatene. Hvilken rolle spiller guruen og hans lære for hvordan instruktørene formidler meditasjonsteknikkene overfor forskjellige publikum? Og hvordan skiller tolkningene til mediterende som tilhører sanghaen seg fra dem som kommer utenfra? Med disse interesser knytter jeg meg til diskusjonen rundt populariseringen av meditasjon og spørsmålet om hvorvidt trenden medfører en sekularisering av praksisen.

Artikkelen bygger på min pågående etnografiske forskning og doktorgradsprosjekt om nåtidige resepsjoner av den indiske guruen Osho (Bhagwan Shree Rajneesh) og bevegelsen rundt ham i Europa og India. I denne sammenhengen har jeg gjennomført feltarbeid på meditasjonssentre med ulike former for tilknytning til Osho i flere land. På det norske Dharma Mountain har jeg deltatt på tre retreater ${ }^{1}$ og tilbrakt til sammen rundt fem uker i 2019 og 2020. Datagrunnlaget til denne studien består hovedsakelig av feltnotiser fra deltagende observasjon, som jeg fører sammen med semistrukturerte intervjuer med retreat-deltagere og material som Dharma Mountain selv legger ut på nettsidene sine. Min tilnærming til både feltarbeid og dataanalyse er preget av kunnskapssosiologiske former for etnografi som blant annet Hubert Knoblauch (2005), Anne Honer og Ronald Hitzler (2015) har fremmet.

Etter en kort skisse av forskning på populariseringen av meditasjon, begynner jeg i det følgende med å gi en oversikt over Dharma Mountains virksomhet. Først vil jeg belyse betydningen av mesteren Vasant Swaha for retreatstedet og disippel-fellesskapet rundt ham, samt utforske hans bakgrunn i bevegelsen rundt Osho. Deretter skal jeg ta for meg Dharma Mountains utadrettede selv-presentasjon og markedsføring. Jeg vil vise at arrangørene slutter seg til samtidens populærkultur og nedtoner rollen til guruen utad,

1. Jeg har deltatt på to sommerretreater med Vasant Swaha (ti dager i 2019, 21 dager i 2020) og helgeretreaten «Tilstede» uten Vasant Swaha sommeren 2020. Intervjuene ble gjennomført under sommerretreatene. 
noe som kan tyde på at guru-konseptet ikke er like populært som meditasjon. For å undersøke hvordan ulike retreatformer og deltagerprofiler henger sammen, tar jeg for meg to veldig ulike meditasjonsteknikker som på grunn av forskjellene viser seg å være spesielt oppklarende: Vipassana og Dynamic Meditation. Ved å kontrastere dem og bruken av dem i nybegynner-retreater versus retreater med Vasant Swaha, vil jeg vise hvordan praksisene i ulik grad knyttes til Swahas lære og sanghaen. Artikkelen er et empirisk bidrag til studiet av samtidige former for meditasjon og retreatturisme i Norden, og forskning på forholdet mellom religiøse fellesskap og nye former for meditasjon mer generelt.

\section{POPUL $\nRightarrow R$ MEDITASJON}

At meditasjon gjennom de siste tiårene har blitt populært kommer tydelig fram av statistiske studier i ulike land som viser at en stadig voksende andel av befolkningen praktiserer forskjellige former for meditasjon (Frisk og Åkerbäck 2013; Heelas og Woodhead 2005; Höllinger og Tripold 2012; Knoblauch 2010, 2013; Pagis 2019a: 32-39). Retreater som tilbyr meditasjon og yoga utgjør ikke bare en betydelig trend i global turisme (Stausberg 2011: 130-134; Pagis 2019b; Endresen 2018), men har også blitt en av de «samtida religiösa arenor» (Frisk og Åkerbäck 2013: 111-116) på lokalt nivå. Med sitt fokus på opplevelser, kroppslig erfaring og individuell utvikling samt sine tidsbegrensede fellesskap, representerer retreat-formatet sentrale trender i senmodernitetens religiøse landskap (Knoblauch 2013; Repstad og Trysnes 2013; Repstad 2020; Frisk og Åkerbäck 2013). Som flere forskere har påpekt, har grensene mellom religiøst og sekulært, mainstream og alternativt blitt stadig mer utydelige (Frisk og Åkerbäck 2013: 226; Knoblauch 2010). Det å dra på en meditasjonsretreat forstås av de fleste deltagere ikke som en religiøs aktivitet, samtidig som tilbydere av meditasjonsretreater også gjerne avviser koblingen til 〈organisert religion〉. Suksessen til MBSR (Mindfulness Based Stress Reduction) (se Plank 2014) og ACEM (se Løøv 2015) i Norden eksemplifiserer en utbredt tendens til å løsrive praksisene fra sør- og østasiatiske kulturelle og religiøse kontekster og i stedet gi dem et sekulært, terapeutisk rammeverk med vitenskapelig legitimering. Samtidig har det foregått en spredning av idéer fra New Age og Human Potential Movement, som sakraliseringen av selvet (Heelas 2009; Frisk 2016), uten at disse lenger knyttes til nyreligiøse bevegelser og deres motkulturelle bakgrunn.

Selv om idéer og praksiser fra det alternativreligiøse feltet siver inn i mainstreamkulturen og grensene mellom det religiøse og det sekulære blir flytende, er disse tendensene ikke de eneste som preger samtidsreligiøsitet. Min etnografiske forskning på Dharma Mountain viser at popularisering og avfortrylling kan foregå parallelt med en ny markering av religiøse grenser. På retreatstedet kombineres ulike tradisjoner og teknikker i en ny sosial sammenheng. Det spennende med Dharma Mountain er dog at stedet drives av og ikke minst for et fellesskap orientert mot en åndelig leder. 


\section{DHARMA MOUNTAIN OG «GURUEN I GRANSKOGEN»}

Dharma Mountain Meditation and Freedom Resort is built up around the mystic Vasant Swaha. [...] Here Swaha shares with us his wisdom, joy, silence and love. Seekers from all over the world are coming to join his retreats. From this space many other activities and groups have been created and invited, along with the inspiration to make the place more and more beautiful - and so the flowering of Dharma Mountain unfolds (Dharma Mountain 2021a).

I denne beskrivelsen fra Dharma Mountains nettside blir «mystikeren Vasant Swaha» til den metaforiske kjernen til stedet, som andre aktiviteter har sprunget ut av. For en utenforstående som besøker nettsiden uten å lese denne lille teksten er forholdet mellom Dharma Mountain og Vasant Swaha ikke lett å skjønne. Vasant Swaha har nemlig en egen nettside. Utfyllende informasjon om ham og retreatene ligger bare der. På Dharma Mountains nettside fremstår stedet nettopp som et «Meditation and Freedom Resort» med et mangfoldig tilbud og Swahas retreater som et arrangement blant mange andre. Denne todelingen av virksomheten gjelder ikke bare nettsiden, men selve arrangementene og deltagergruppene som disse tiltrekker. Jeg skal, i feltets språk, først utforske kjernen og så blomstene.

\section{RETREATSTEDETS KJERnE: SATSANG MED Vasant Swaha}

Dharma Mountain ble etablert i 2000 i lokalene til en gammel gjestegård i Hedalen, en bygd nær Vassfaret i Sør-Aurdal, Valdres. Senteret er omgitt av storslått natur, med høye fjell, dyp skog og en vill elv. Formålet og kjerneaktiviteten til senteret er retreatene med Vasant Swaha som slo seg ned i området sammen med 35-40 tilhengere (Selberg 2009: 33). På dette tidspunktet hadde Swaha allerede holdt meditasjonsretreater og satsang ${ }^{2}$ i flere land, blant annet i Sverige ( ̈̈ngsbacka) og i Brasil. Hans brasilianske tilhengere stiftet i 2009 et tilsvarende meditasjonssenter i Brasil som i dag heter Mevlana Garden

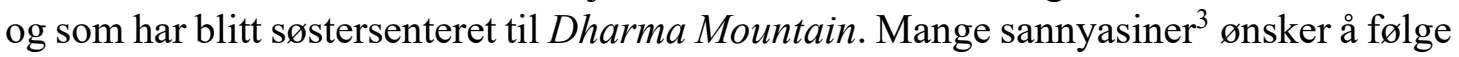
Swaha når han reiser frem og tilbake mellom Brasil og Norge og deltar på retreatene $\mathrm{i}$ begge land.

2. Begrepet satsang, fra Sanskrit for «samvær i/med sannhet», brukes i feltet for å betegne det å sitte i selskap av en mester som representerer sannheten (se Frisk 2002).

3. Begrepet sannyasin i Hindu-tradisjonen betegner en vandrende asket som har trukket seg tilbake fra hverdagslivet for å konsentrere seg om spirituell utvikling (se Olivelle 2018). Osho karikerte denne institusjonen ved å kalle sine initierte tilhengere for «(neo-)sannyasins», som i motsetning til tradisjonelle sannyasiner bare skulle avstå fra sosiale normer og var alt annet enn kyske. Vasant Swaha har overtatt begrepet og initierer også sannyasiner. 
Vasant Swaha, som borgerlig heter Tor Opheim, er fra Bergen. Nettsiden hans forteller om en rebelsk ungdom som reiste rundt i verden på søken etter åndelig innsikt. I 1977 fant han veien til Poona (Pune) og ble disippel av guruen Bhagwan Shree Rajneesh (senere kalt for Osho) (1931-1990). Han ble med Osho frem til han døde i 1990, jobbet som en av Oshos livvakter i Poona og flyttet også med Osho til senteret i Oregon på midten av 80-tallet. Som mange andre Osho-sannyasiner etter Oshos død reiste også Swaha til Lucknow i Nord-India der H. W. L. Poonja (Hariwansh Lal Poonja, også kalt for Papaji) (1910-1997), en Neo-Advaita-guru i Ramana Maharshis tradisjonslinje, holdt til og ga satsang. Et sentralt tema i dette miljøet og under Poonjas satsanger var «opplysning» eller «oppvåkning», som ble omtalt som noe som uanstrengt kunne oppnås (Frisk 2002; Jacobs 2020). Som følge av denne demokratiseringen av «opplysning» vokste det fra 1990-tallet frem det som Frisk kaller for «the Satsang network» (Frisk 2002) og Lucas for «non-traditional modern advaita» (Lucas 2014): en rekke åndelige lærere som med utgangspunkt i sin egen, påståtte opplysning gir satsang selv. Vasant Swaha er en av mange skikkelser i nettverket-Mooji, Gangaji, Eli Jaxon-Bear er noen av de mest kjente-men den eneste nordmannen. ${ }^{4}$ I likhet med andre satsang-lærere, fortelles det også på Swahas nettside at han etter Oshos død opplevde en «awakening to his true Self»:

I was no longer the one I was the day before. I had no identification with any personality or ego. The «I» was gone, and so was the whole past. I was drowned in a profound peace, in a deep spaciousness and blissful silence. It was a new birth. I became very fragile, I had to learn how to function in the world again (Vasant Swaha 2021c).

Opplysningsnarrativet viser til noen grunnleggende antagelser som preger Swahas lære og som er hentet fra både Osho og den moderne Advaita-tradisjonen, som gjenfortolker sør-asiatiske frelsesforestillinger på en psykologiserende måte. Idéen er at mennesker har et iboende sant Selv som på grunn av destruktive krefter i samfunnet—og ikke minst tradisjonell religion - ligger bak et slør av falske forestillinger og egoet. Målet med den åndelige veien er å skrelle bort kondisjoneringen for å våkne opp til det som er «sant». Mesteren fungerer som en veileder og skal hjelpe disippelen på sin egen indre reise mot oppvåkning. Swaha og hans kolleger anses av følgerne sine som levende bevis på at denne oppskriften fungerer. Men det er ikke bare denne idéen om opplysning og legitimeringen den gir til guru-rollen som Swaha har overtatt fra Osho og Poonja. Praksisene som læres bort under retreatene er også i stor grad inspirert av dem, som vi vil se i diskusjonen om meditasjonspraksisen lenger nede. I likhet med Osho innvier Swaha disipler.

4. Vasant Swaha er et av Frisks empiriske eksempler i artikkelen som analyserer en rekke «opplyste» som på den tiden regelmessig besøkte Sverige (Frisk 2002: 65). 
De får et nytt navn av ham, og blir gjennom innvielsen til sannyasiner. Fellesskapet refereres til som sangha, et buddhistisk begrep som betegner fellesskapet av de som følger Buddhas vei. Slik som i Oshos tid føler også mange av Swahas disipler behovet for å være nærmest mulig mesteren og har flyttet til Hedalen eller til strøkene rundt det brasilianske senteret. Området rundt sentrene forstås som buddhafields, det vil si steder ladet med en spesiell meditativ energi som gjør det spesielt virkningsfullt å oppholde seg og meditere der.

Vasant Swaha holder treukers retreater på Dharma Mountain hver sommer og noen kortere retreater i sommersesongen samt vinterretreater omtrent annet hvert år. Resten av året bor han i Brasil og holder retreater der på Mevlana Garden. ${ }^{5}$ Når det sies at Swaha holder retreater, så er det viktig å fremheve at størsteparten av arrangementet—slik som hele den administrative og praktiske driften av stedet — drives av hans nære disipler. Mange av disiplene som leder retreatene har bakgrunn fra ulike former for alternativ, kroppsbasert terapi, og flere har gått på kurs ved det danske senteret Osho Risk. ${ }^{6}$ Det er disse som veileder ulike former for meditasjon, self-inquiry ${ }^{7}$ og terapeutiske grupper under retreatene.

Swaha selv møter kun til satsang, som finner sted fire dager i uken når det er retreat og varer i omtrent to timer. Under satsang leser Swaha opp brev som disipler og andre deltagere har sendt ham og svarer på dem. Dette tilsvarer måten også Osho holdt sine «discourses» på. Andre satsang-lærere går ofte i direkte dialog med deltagerne (se Frisk 2002: 67), noe som i liten grad skjer under Swahas satsanger. Han henvender seg til de som har sendt inn spørsmål og også andre i publikum, men opplegget er mer monologisk enn dialogisk. Dette samsvarer med at Swahas stil er sterkt orientert mot Osho og guruinstitusjonen. I likhet med andre satsang-arrangementer kjennetegnes også møtet med disiplene av et fokus på følelser (se Frisk 2002: 67). Brevene til Swaha pleier å være veldig personlige og det er vanlig at ikke bare den som har stilt spørsmålet, men også andre deltagere, gråter. Etter god Osho-skikk er også latter en sentral del av satsang og Swaha spøker gjerne med publikumet eller leser opp vitser. Som Frisk observerer for

5. Det at navnene til Vasant Swahas sentre refererer til både sørasiatiske religioner (dharma) og sufisme (Mevlana) er kjennetegnende for tradisjonen til Osho. Osho blandet sammen religiøse referanser som for ham var uttrykk for mystiske strømninger som går på tvers av religioner (se OSHO 2000: 236).

6. Osho Risk er et dansk senter i Østjylland, som både er en kommune hvor en gruppe Osho-sannyasiner lever permanent, og et møtested for Osho-miljøet. I tillegg til å arrangere workshoper, festivaler og retreater, tilbyr senteret også treningsprogrammer for Osho-terapeuter (se https://www.oshorisk.com/).

7. «Self-inquiry» (ātma vicāra) er en teknikk preget av Advaita Vedānta-guruen Ramana Maharshi (1879-1950) som innebærer å stille seg selv spørsmålet «Who am I?» for å løse opp identifikasjonen med egoet og realisere selvets enhet med Brahman, den absolutte virkeligheten. Lik læreren sin formidlet også H. W. L. Poonja self-inquiry som den viktigste åndelige teknikken (se Lucas 2014). Osho tok teknikken også i bruk, blant annet i en tidligere versjon av Dynamic Meditation (se OSHO International Foundation 2018: 15-16). Som på Dharma Mountain praktiseres det fortsatt versjoner av «self-inquiry» i det samtidige Osho-miljøet. 
satsang-miljøet, spiller musikk og dans også en viktig rolle under satsang på Dharma Mountain. Også under Swahas satsang bæres den affektive dramaturgien av musikk, ofte vestliggjorte mantra-sanger eller New Age-musikk, og både Swaha og deltagerne danser av og til. En grunnantagelse med satsang er at det er selve samværet med en opplyst som virker transformativt. Swaha forklarer det som å komme i takt med mesteren: «That is the art of the Masters, that is Satsang - to fall in tune, to fall in tune with the Master, and in that way you fall in tune with yourself. You start remembering your divine Being» (Vasant Swaha 2021b). Samtidig som mesterens relevans fremheves, påpekes det også at det ikke er noe endelig skille mellom mesteren og ens egen «true Self» eller «Being». Dette er også kjennetegnende for satsang-nettverkets form for Neo-Advaita.

Sammenfattende kan denne delen av Dharma Mountains virksomhet beskrives som et fellesskap av innvidde som er sterkt orientert mot mesterfiguren Vasant Swaha og idéen om opplysning i tradisjonen til Osho og H. W. L. Poonja. Riktignok finnes det ulike grader av hengivenhet og forskjellige motivasjoner blant disiplene, men Swaha og idéene han formidler danner en felles gruppeidentitet som sannyasiner. Selv om Vasant Swaha og sannyasinene jeg har snakket med pleier å avvise begrepet «religion» til fordel for «spiritualitet» eller «åndelighet», er henvisningen til en «stor transcendens» (Luckmann 1990: 129) i form av «opplysning» eller «oppvåkning» definerende for gruppens identitet. I tråd med Thomas Luckmanns begreper kan vi derfor forstå Swahas sangha som et religiøst fellesskap. Samtidig er dette fellesskapet bare en del av retreatstedets virksomhet. Som vi vil se i neste avsnitt, åpner Dharma Mountain også dørene for deltagere utenfra sanghaen.

\section{«The Flowering of Dharma Mountain unfolds»: Markedsføring og POPULARISERING}

Selv om retreatene med Vasant Swaha var grunnen til at Dharma Mountain ble etablert, er de bare ett av mange tilbud på senteret. I programkalenderen finnes en hel rekke andre arrangementer som ved første øyekast ikke er forbundet med guruen. Lokalene leies regelmessig ut til eksterne tilbydere som ikke tilhører sanghaen, og det står blant annet yoga- og permakultur-arrangementer ${ }^{8}$ på programmet. I tillegg har Dharma Mountain siden 2018 tilbudt egne retreater som markedsføres til et bredere publikum. Denne utviklingen er et resultat av at senteret de siste årene har ønsket å dele meditasjon med flere deltagere, og har gjennomgått en institusjonaliserings- og profesjonaliseringsprosess. Ser vi på denne utadrettede siden av retreatstedet, kommer de spesifikke trekkene med et mester-orientert fellesskap som jeg har beskrevet ovenfor i bakgrunnen.

8. Permakultur er et konsept fremmet av australske Bill Mollison og David Holmgren på 1970-tallet, og utviklet seg fra å være et system for bærekraftig landbruk til en holistisk bevegelse som ønsker å etablere en bærekraftig livsstil i takt med naturen (Gibsone og Bang 2015). 
De nye retreatene har navn som «Tilstede», «Gave» eller «Inner Peace» og markedsføres i en stil som er typisk for retreatsteder:

Er du lei av å prestere, og hele tiden skynde deg for å få ting gjort? Er det vanskelig å finne roen og gleden ved bare å være? Trenger du å stoppe opp og kjenne etter hva du egentlig vil? Denne mini-retreaten er en mulighet til å stoppe opp, få litt avstand til hverdagen og gi rom for deg selv (Dharma Mountain 2021c).

Konseptet «retreat» betegner nettopp det å trekke seg tilbake fra hverdagslivet i en viss tidsperiode og bokstavelig talt koble av. På mange retreatsteder forbindes dette med en kritikk av det moderne livet som fremstilles som hektisk og stressende. Også her presenteres det å dra på retreat som et hjelpemiddel for å håndtere hverdagens mas og kjas. Retreaten attribueres et transformativt potensial ved å gi deltageren rom til å bli klar over «hva du egentlig vil». Disse topoi og fortellinger er karakteristiske for hele den «holistisk turisme»-sektoren (Heintzmann 2012; Smith og Kelly 2006) og har blitt popularisert gjennom medialiserte fremstillinger. To velkjente eksempler på slike fortellinger, Lonely Planet India-bøkene (se Kraft 2007) og den populære romanen og filmen Eat Pray Love (Gilbert 2006), gjenfinnes begge to i Dharma Mountains lille bibliotek. I tillegg er det spesielt sosiale media som har spredd estetiserte forestillinger om det å reise bort for å finne seg selv. Med sine retreater uten Vasant Swaha skriver Dharma Mountain seg inn i denne populære diskursen.

Naturen spiller en hovedrolle i den visuelle fremstillingen og markedsføringen av retreatstedet. I likhet med andre former for turisme i Norge (se Fonneland 2013), trekkes opplevelsen av vill natur knyttet til kraftsteder frem. På bildene vises den flotte naturen på stedet—blåbærbusker, bjørketrær, granskog-sammen med personer med lukkede øyne og fredfulle uttrykk, noe som formidler inntrykket av at deltagerne blir omfavnet av naturen og kjenner naturens ro. Naturen rundt Dharma Mountain blir også innlemmet i retreat-programmet som «skogsbad». Denne teknikken for å redusere stress ved å vandre gjennom skogen på en mindful måte har blitt en globalisert og sertifisert metode som føres tilbake til det japanske konseptet «shinrin-yoku» (se Knight 2000).

Noen av de største trendene på retreatmarkedet er yoga og vipassana. Sistnevnte blir oftest lært bort i læretradisjonen til S. N. Goenka (Satya Narayan Goenka) under retreater som holdes i stillhet (Pagis 2019a). Vipassana og stillhet er noen av hovedingrediensene i Dharma Mountains mini-retreater, og yoga blir også tilbudt. Praksisene som er spesifikt knyttet til Swahas bakgrunn-Oshos aktive meditasjoner og self-inquiry (eller self-enquiry) i Poonja/Ramana Maharshi-tradisjonen — nevnes også i programbeskrivelsen, men deres tilknytning til en spesifikk tradisjon nevnes ikke. I beskrivelsen til helgeretreaten «Tilstede» blir «self-inquiry» beskrevet som en «metode for å bli mer kjent med deg selv» (Dharma Mountain 2021c). Osho-meditasjonene markedsføres også bare indirekte som «aktive meditasjoner». Guruene selv er fraværende i annonsen. I stedet 
refereres det til vitenskapelige studier som viser til den positive effekten av meditasjon på nivået av stresshormoner i kroppen. Trender blir fremhevet, noe som korresponderer med at deltagerne jeg snakket med ble tiltrukket av nettopp vipassana, stillhet, yoga eller skogsbad. Et spesielt virkningsfullt verktøy virker å være Google Ads, siden de fleste deltagere på helgeretreaten «Tilstede» fortalte om at de fant stedet ved å google «meditasjon retreat Norge», «vipassana retreat Norge» eller lignende.

Senteret slutter seg til populære diskurser rundt retreater som tar utgangspunkt $i$ et bilde av det moderne livet som stressende og mangelfullt. Meditasjonsretreater fremstilles som en sjanse til å hente seg inn eller til og med forandre hele livet til det bedre. Mens muligheten for religiøse tolkninger ikke fratas, er motivasjonen for å dra på retreat ofte knyttet til immanente forhold. Målet er ikke å våkne opp eller bli opplyst. Målet er å koble av og ha det bedre. Likeledes som transcendente målsetninger uteblir, er senterets kjerne, mesteren Vasant Swaha såvel som hans egne guruer lite synlige i den offentlige fremstillingen av retreater som «Tilstede».

Torunn Selberg (2009) har gjort en analyse av mediediskusjoner rundt Dharma Mountain på begynnelsen av 2000-tallet. Analysen viser at særlig det faktum at stedet var knyttet til en guru skapte negative reaksjoner. Selberg argumenterer videre for at guruer mistenkes for sjarlataneri og maktmisbruk, spesielt i norsk sammenheng der alminnelighet verdsettes. Det å latterliggjøre Swaha ved å nedsettende kalle ham for «guruen i granskogen», som noen journalister gjorde, er ifølge Selberg en strategi for å gjøre det ukjente kjent og mindre skummelt (Selberg 2009: 37-38). Siden etableringen av Dharma Mountain har det gått 20 år. Sannyasiner som bor i Hedalen forteller at de har blitt gode naboer med hedølene og at de generelt opplever en større nysgjerrighet i samfunnet enn for 20 år siden. At en viss grunnskepsis overfor nyåndelige autoriteter fortsatt står sterkt i den offentlige debatten, viser reaksjonene på Prinsesse Märtha Louises forhold til Shaman Durek (se Tjellaug og Pecori 2019). Mens praksiser som yoga og meditasjon har blitt delvis avfortryllet, innlemmet i sekulære sammenhenger og blitt en fast bestanddel av nyåndeligheten, har ikke guru-konseptet blitt det i like stor grad. Selv i alternativmiljøet står subjektets autonomi høyt, og lite forpliktende «guru-hopping» er mer verdsatt enn medlemskap i en guru-bevegelse (Höllinger og Tripold 2012: 32; Heelas og Woodhead 2005).

På helgeretreaten «Tilstede» hadde de fleste deltagerne ikke fått med seg at Dharma Mountain var knyttet til en guru. Flere reagerte med overraskelse da de skjønte at instruktørene var disipler. Noen moret seg over det, andre var mer nysgjerrige. Samtidig var guruen og relasjonen til ham på det meste et tema deltagerne snakket om, men ikke noe de måtte aktivt forholde seg til. På Swahas sommerretreater, hvor også førstegangs deltagere var bevisste på at Vasant Swaha var sentral for opplegget, var bildet mer sammensatt. Karoline, som hadde møtt sannyasiner fra sanghaen før, fortalte at det var en YouTube-video av Vasant Swaha som fikk henne til å melde seg på retreaten: 
Jeg så en video av Swaha på YouTube og jeg følte med en gang at han snakket til meg og at jeg... Jeg var veldig berørt av det han sa og det var en følelse inne i meg som... det var en slags frykt og derfor begynte jeg å gråte fordi jeg visste at det er dette jeg må gjøre, dette er... dette trenger jeg å gjøre hvis jeg virkelig vil være lykkelig, så må jeg gå denne veien, jeg må virkelig møte meg selv [...] (Intervju med Karoline, 2019).

Emil var mer forsiktig og sa at selv om han hadde hørt mye negativt om guruer-han nevner voldtektsanklager og skandaler — så går det an å skille mellom gode og dårlige guruer: «[J]eg føler at jeg har blitt flink til å se hva som er hva og jeg kjenner igjen [...] gode ålreite folk som gjør dette av gode grunner» (Intervju med Emil, 2020). Selv om han så på Swaha som en av de «gode ålreite», så beskriver han guru-rollen som potensielt problematisk. Andre nybegynnere uttrykte eksplisitt avstand eller skepsis overfor guruen. Olivia sa: «Jeg har egentlig ikke brydd meg så mye om dette med guru. [...] Jeg gjør dette her av andre interesser» (Intervju med Olivia, 2020). ${ }^{9}$ Elisabeth fortalte at hun bare kom for å meditere, ikke for å møte guruen, og forklarte: «Jeg er veldig skeptisk overfor autoritetsfigurer, spesielt menn, som alle dyrker som opplyste eller noe sånt» (Intervju med Elisabeth, 2020).

Dette spekteret av holdninger til guruen som går fra entusiasme, via mistro til avvisning, er retreat-arrangørene nok bevisste på. På sommerretreatene finnes det for eksempel såkalte «newcomer meetings» hvor nybegynnere kan dele sine opplevelser og bekymringer med instruktørene. Men Dharma Mountain tematiserer guru-institusjonen også ved å nå ut til det bredere alternativmiljøet i form for publikasjoner. I en artikkel om en retreat med Swaha i magasinet Visjon intervjuer artikkelforfatteren og Dharma Mountain-arrangør Line Nyborg Vasant Swaha og spør: «Hvis jeg forteller mennesker jeg møter om deg, kan jeg merke motstand og skepsis. Hvorfor er det så mye motstand i samfunnet vårt til det å ha en mester, og hva går vi glipp av?» Swaha svarer ved å si: «Sannheten er alltid skremmende for dem som lever i løgn». Han nevner henrettelsen til Jesus og Sokrates som eksempler og tilføyer at folk går glipp av «[e]t liv i frihet» (Nyborg 2017: 11). Swaha svarer på en konfronterende måte ved å identifisere dem som føler motstand, med løgn og ufrihet og seg selv med sannhet og frihet—på lik linje med Jesus og Sokrates. Samtidig som han diskrediterer guru-skepsisen, løfter han også frem fordelen ved å følge ham.

Mester-disippel-forholdet er nødt til å legitimeres og artikkelen i Visjon er en måte Swaha og Dharma Mountain gjør det på overfor det alternative miljøet som er kjent

9. Med mindre intervjuet ble holdt på norsk, er sitatene oversatt til norsk av forfatteren. På grunn av hensyn til datavern, er ikke dette merket. Navnene er endret for avidentifiseringens skyld og siden dette ikke blir gjenstand for analysen, tilsvarer aliasene ikke nødvendigvis kjønnsidentitet eller kulturell bakgrunn. 
med diskursen rundt guruer og autoritet. ${ }^{10}$ Overfor et enda bredere publikum som er målgruppen for mini-retreatene, velger Dharma Mountain å holde mesteren utenfor og i stedet løfte frem praksiser som vipassana og yoga, som er veletablerte i mainstreamkulturen.

\section{MEDITASJONSTEKNIKKER FRA GENERISK TIL MARKERT: FORMIDLING, LEGITIMERING, TOLKNING}

Som vi har sett, er meditasjonsretreatene på Dharma Mountain sammensatt av mange forskjellige praksiser som blir kombinert på ulikt vis på de ulike retreatformatene. For å forstå spennvidden av det som omfattes av meditasjon på Dharma Mountain, skal jeg undersøke to meditasjonsteknikker som praktiseres på retreatene nærmere: vipassana og Dynamic Meditation. Jeg skal se spesielt på formidlingen av meditasjonene, siden det er her vi får innblikk i hvordan praksisene innrammes og legitimeres. Formidlingssituasjonen gir også informasjon om hvordan praksisen henger sammen med sosiale roller, forholdet til guruen og sanghaen.

\section{VIPASSANA: LAVTERSKEL-MEDITASJON I TRADISJONEN TIL (ZORBA THE) BUDDHA}

Sommeren 2020 sitter jeg sammen med rundt 20 andre deltagere og tre instruktører i en krets i Dharma Mountains meditasjonshall. Meditasjonsstolene våre er plassert med en meters avstand, vi er tross alt midt $i$ en pandemi. Det er den første morgenen av helgeretreaten «Tilstede». Etter å ha varmet opp kroppen med litt Tai Chi skal vi nå få en introduksjon til vipassana. Bare to av oss har vært på Dharma Mountain før, alle andre har mer eller mindre tilfeldig havnet her fordi de har vært på utkikk etter en retreat i Norge og fant Dharma Mountain på internett. Mange kommer nettopp fordi de har hørt mye godt om vipassana, noen har lyst til å supplere sin yogapraksis med mer meditasjon, og andre forteller at de er utslitte og trengte tid for seg selv. De fleste deltagere er kvinner mellom 30 og 60 .

Instruktørene er tre kvinner som har introdusert seg selv med tilsynelatende indiske navn og forklart at de har lang meditasjonserfaring gjennom retreatene med Vasant Swaha, «en åndelig lærer, eller guru hvis du vil». ${ }^{11}$ De vil gjerne dele det de selv har lært, nemlig at meditasjon kan være enkelt og naturlig. Helgen, sier de, skal være en smakebit av hva meditasjon kan være. I løpet av disse tre dagene skal de lede gruppen gjennom

10. At åndelige autoritetsfigurer er et ømtålig tema i alternativmiljøet viser det autoritetskritiske innlegget som Christian Paaske, en av det norske alternativmiljøets veteraner og talsmenn, publiserte som svar til artikkelen i Visjon (Paaske 2017).

11. Beskrivelsen og sitatene er basert på min deltagende observasjon og feltnotatene jeg skrev ned i etterkant. 
forskjellige aktiviteter: skogsbad, selv-utforskning i grupper, dans, Tai Chi, Kundalinimeditasjon (en av Oshos aktive meditasjoner) med mer. Vipassana som vi skal prøve oss med nå, er en teknikk som vi kommer tilbake til gjennom hele helgen.

«Vipassana», sier en av veilederne, «er teknikken Gautama Buddha har introdusert». De forklarer at i vipassana er det pusten som hjelper oss å være tilstede ved at vi observerer hvordan pusten kommer inn og ut av kroppen. Det er viktig, sier de, å sitte med rett rygg for å holde oppmerksomheten og unngå å sovne. Samtidig skal kroppen være så avslappet som mulig og vi oppfordres til å eksperimentere med forskjellige puter for å sitte mest mulig komfortabelt. Når alle har funnet en sitteposisjon, leder en av instruktørene oss inn i meditasjonen og oppfordrer oss til å finne ut hvor det er lettest for oss å observere pusten. Hun sier at det er naturlig å bli distrahert av tanker og miste fokuset på pusten, men at det da bare er å observere dette også og føre oppmerksomheten tilbake til pusten på en vennlig måte.

Det er påfallende at meditasjonen introduseres som en teknikk med et spesifikt navn, vipassana, og en spesifikk opprinnelse, nemlig Gautama Buddha. Slik som den introduseres har altså meditasjonen ingen direkte tilkobling til Dharma Mountain, Vasant Swaha eller hans lærere, men presenteres i stedet som en eldgammel buddhistisk metode. Men som mange religionshistorikere har vist, utspringer dagens vipassana fra en reformbevegelse innenfor burmesisk Theravada-buddhisme. På 1950-tallet ble buddhistisk meditasjon gjenoppfunnet og popularisert ved å refortolke teksten Satipatțthāna Sutta og konstruere en meditasjonsteknikk for lekfolk (se Braun 2013). Denne bevegelsen har spredt vipassana også til Vesten, hvor teknikken har fått fotfeste særlig gjennom meditasjonssentrene i tradisjonen til S. N. Goenka. Den har også preget spredningen av mindfulness (se Pagis 2019a: 19-44). I de fleste vipassana-retreatene er teknikken som læres bort mer avansert enn på Dharma Mountain, som formidler en versjon som bare innebærer å holde oppmerksomheten på pusten. Instruktørene angir også nettopp denne enkeltheten og naturligheten som en forskjell fra andre steder som tilbyr vipassana.

Selv om meditasjonen presenteres som en «svært enkel metode» (Dharma Mountain 2021c) som går tilbake til Buddha, bærer nettopp denne fremstillingen Vasant Swahas og Oshos signatur. Vipassana inngår nemlig også i Oshos meditasjoner som Osho International Foundation ${ }^{12}$ har til og med copyright-beskyttet teknikken under navnet OSHO Vipassana Meditation ${ }^{\mathrm{TM}}$. På Osho-sentre praktiseres vipassana mest med 45 minutter sittende og 15 minutter gående meditasjon, men det åpnes for variasjoner. Måten instruktørene på Dharma Mountain introduserer meditasjonen på er svært lik som

12. OSHO International Foundation (OIF) er organisasjonen som har opphavsrett til alle Oshopublikasjoner, meditasjonsteknikker og terapier. Den har til og med eierskap til varemerket «OSHO». Organisasjonen driver det tidligere hoved-ashramet i Pune som i dag heter OSHO International Meditation Resort og fører tilsyn med Osho-sentrene rundt i verden. OIFs rolle er omstridt blant sannyasiner og gjenstand for juridiske tvister (se Urban 2015: 155-178). 
vipassana forklares i OSHO-meditasjonsbøker og på OSHO.com: «This meditation is based on a method of Gautama the Buddha. It is for practicing awareness, watchfulness, mindfulness, witnessing. The OSHO form of vipassana enables this to be a comfortable, 〈juicy〉 experience, it is not dry» (OSHO International Foundation 2019b; OSHO 2013: 125). På Oshos tid var dette en tydelig avgrensning fra S. N. Goenka og hans theravadabuddhistiske forståelse av vipassana, som Osho gjentatte ganger kritiserte og latterliggjorde for dens tekniske tilnærming til vipassana (se OSHO 1988). Selv om det fortsatt er denne forståelsen av vipassana Dharma Mountains instruktører fremmer, gir den seg nå til kjenne i form av subtile aksentueringer overfor andre tradisjoner, ikke eksplisitte konflikter.

Osho kalte sitt ideal for et nytt menneske for «Zorba the Buddha». Med dette siktet han til en person som er både spirituell og materiell, som både fester som «Zorba the Greek», en romanfigur av Nikos Kazantzakis, og mediterer som Gautama Buddha (Urban 2015: 3). Vasant Swaha pleier å gjengi noen av Oshos hyppig brukte ordtak «Easy is right» (se f.eks. OSHO 2013). Som Osho oppfordrer han disiplene først og fremst til å slappe av: «Relax!» (OSHO 2013: 12). Oppfordringen til å sitte så bekvemt som mulig kan forstås i denne sammenhengen. Meditasjon skal være en nytelse, ikke selvpining, og Osho gjorde ofte narr av asketiske meditasjonstradisjoner. Selv om det henvises til Buddha, er det tydelig at Zorba har satt sitt preg på Oshos og Dharma Mountains versjon av vipassana.

Det har blitt tydelig at vipassana på Dharma Mountains nybegynner-retreater både er en åpen og generisk meditasjonsteknikk, samtidig som den er innpasset i retreatstedets læretradisjon. Vipassana er på den ene siden et iøynefallende eksempel på det Thomas J. Csordas kaller en «portable practice». En slik praksis eller ritual kan enkelt læres og utøves uten spesielt mye insider-kunnskap, organisatorisk styr og uten å forplikte seg til en spesifikk ideologi eller institusjon. Dermed kan den også lett tilpasses forskjellige kulturelle kontekster (Csordas 2009: 4). På den andre siden er praksiser som vipassana også forhandlingsfelt der ulike religiøse og sekulære aktører markerer sine grenser. Det markedslignende meditasjons- og retreatlandskapet utfordrer aktørene til å tilby tolkningsåpne praksiser, samtidig som de er nødt til å skille seg ut og markere sitt særpreg (se Karapanagiotis 2021: 15-16). Med vipassana tilbyr Dharma Mountain-gruppen en teknikk som fungerer for nybegynnere uten å kreve noen som helst bekjennelse eller tilknytning til guruen, men som ikke bryter med guruen heller, siden tradisjonslinjen er inkorporert i måten praksisen presenteres på. Deltagerne på «Tilstede» rapporterte etter helgen at de følte mer ro, at de nøt stillheten og kontakten de fikk med seg selv gjennom meditasjon, men ingen snakket om veien til oppvåkning eller uttrykte behovet for en mester, noe som derimot er utbredt blant Swahas disipler. Dette illustrerer at vipassana kan oppleves som meningsfylt både av en sekulært orientert deltager og av en hengiven disippel med opplysning som mål. 


\section{DyNAMIC MEDITATION: OSHOS SIGNATURTEKNIKK I NY SAMMENHENG}

Sommeren 2019 står jeg klokken 7 om morgenen i Dharma Mountains meditasjonshall som er tettpakket med omtrent 100 personer som gjør seg klar til «Dynamic Meditation». Noen rengjør nesen, andre tar et bind for øyene. Det er bare en håndfull nybegynnere til stede, størsteparten av gruppen består av sannyasiner, og mange av dem har gjort Dynamic på Swahas retreater i årevis. To instruktører står i fronten, en av dem sier: «So, good morning, friends, welcome to Dynamic Meditation!» Så forklarer de at «Dynamic» er en meditasjon av Osho og forklarer de fem fasene som utgjør den en time lange meditasjonen: 10 minutter «chaotic breathing», 10 minutter «Explode!»—der man skal utagere alt som kommer opp, enten det er latter, skriking, eller puteslåing - 10 minutter «jumping and the mantra 〈Hoo»», 15 minutter «Stop!»- der man fryser som man er og ikke rører seg - og 15 minutter «celebration», der man danser og feirer livet (OSHO 2013: 80-81; Dharma Mountain 2021b). Så ønsker instruktørene oss en vakker meditasjon og slår på musikken som har akkompagnert meditasjonen siden 1970-tallet. ${ }^{13}$

Blant de mange meditasjonsteknikkene som Osho skapte, er Dynamic Meditation (eller «Dynamic») hans mest berømte teknikk. Den ble introdusert da Osho-bevegelsen ble etablert, og er fortsatt den vanlige morgenmeditasjonen på Osho-sentre rundt verdenen. Hugh B. Urban betegner Dynamic som et «mikrokosmos» av Oshos lære og metode (Urban 2015: 59). Det finnes flere gode grunner til denne beskrivelsen. For det første kombinerer Dynamic elementer fra Yoga, «Crazy Wisdom», ${ }^{14}$ sufisme og «Gurdjieff Movements ${ }^{15}$ med impulser fra post-Freudiansk og humanistisk psykologi i tradisjonen til Wilhelm Reich og Arthur Janov. Denne eklektiske kombinasjonen av vestlig psykoterapi med østlige kontemplative tradisjoner er karakteristisk for Osho. For det andre illustrerer sekvensene som leder den mediterende fra katartisk eksplosjon til stillhet og fest, Oshos forståelse av meditasjon. Osho gikk ut ifra at det var så godt som umulig for moderne mennesker å sette seg ned og bare meditere. For at sinnet kunne falle til ro, anså Osho terapi som et nødvendig forarbeid og en måte for individet å bli kvitt den «kondisjoneringen» han mente at samfunnet hadde pålagt individet (se OSHO 2013: 75). Dynamic Meditation er ikke bare en metode for denne typen psykologisk opprydding, men også en slags miniatyr av hele prosessen som skal lede fra kaos til stillhet og lykk-

13. Musikken som ble komponert av Georg Deuter i 1975, kjennetegnes av en blanding av indisk og vestlig instrumentering som støtter fasene ved å gå fra vilt og ekstatisk trommemusikk i begynnelsen til mykt og melodiøst fløytespill på slutten.

14. «Crazy Wisdom» betegner idéen om at tilsynelatende gal atferd kan være en vei til religiøs erkjennelse. I likhet med andre moderne «Crazy Wisdom» guruer som Chögyam Trungpa eller Adi Da tok også Osho «conscious insanity» $\mathrm{i}$ bruk som læremiddel og førte dette tilbake til tantriske idéer (se Urban 2015: 35-39).

15. «Gurdjieff Movements» er en rekke bevegelsesfølger utviklet av Georges I. Gurdjieff med målet om å bryte med fastgrodde væremåter (se Urban 2015: 35-39). 
salighet. Den samme logikken kjennetegner Vasant Swahas retreater. Han oppsummerer sin metode slik:

Først må du tømme deg selv [...]. Slik at du begynner å føle i stedet for å tenke. Slik at du lander, og begynner å kjenne deg mer levende. Da blir det lettere å gå inn i stillheten. Hvis du er utålmodig, rastløs, trist, sint—alt dette som du vanligvis går og bærer på-kan du ikke være stille. Først må alt dette ut. Det er min oppskrift. Meditasjon kan bare skje i et stille sinn (Nyborg 2017: 9).

Under denne sommerretreaten med Vasant Swaha er det Dynamic hver morgen. For de som har booket hele retreaten, betyr det 21 dager med Dynamic Meditation akkurat som Osho anbefalte (OSHO 2013: 80), fordi «Twenty one days is exactly the time the mind takes to change completely, to move into another direction» (OSHO International Foundation 2019a). Dermed er hver enkel Dynamic Meditation-praksis integrert i Swahas oppskrift, som igjen har sitt utspring i Oshos metode. Selv om terapeutisering preger hele meditasjonsmiljøet, er denne bevisste kombinasjonen av teknikker i et prosess-design unikt for Oshos metode som Swaha har overtatt. Til forskjell fra vipassana, som formidles på Dharma Mountain på en generisk måte, løsriver instruktørene ikke Dynamic fra Osho. Denne tradisjonslinjen er med på å legitimere både praksisene og Swahas guruskap. Likevel krever ikke praksisen et spesielt forhold til guruen-hverken til Osho eller til Swaha. De mediterende kan utføre bevegelsene uten å anerkjenne Swahas særstilling, og legge til individuelle tolkninger. Swahas disipler kan likevel knytte praksisen til guruen, noe det følgende sitatet fra en sannyasin viser: «Only with the help of Dynamic can I be open and able to receive the beauty and love that Swaha has to give» (Dharma Mountain 2021b). Dynamic blir i denne tolkningen ikke bare til en nødvendig opprydding for å kunne meditere, men også for å bli mottakelig for mesteren.

Med vipassana på nybegynnerretreaten var det enkelhet og avslapning som ble trukket frem. Det å sette seg ned og lukke øyne er en temmelig lav terskel for deltagelse. Dynamic er på den andre siden krevende. Det å stå klar klokken 7 om morgenen for en intens time av emosjonell, men ikke minst fysisk strevsomme øvelser krever innsats. Nettopp dét formidler også instruktørene når de regelmessig gjengir Oshos «Be total!» (OSHO 2013: 81).

Til sist er det viktig å påpeke at konseptet meditasjon på Dharma Mountain —så som $i$ hele Osho- og satsang-miljøet-ikke bare betegner teknikker, men en spesifikk indre tilstand som gjerne beskrives med engelske ord som «conscious» eller «aware», og i norsk oversettelse ga tittelen til helgeretreaten «Tilstede». Stine, som opprinnelig kom til Dharma Mountain for å teste ut vipassana, forteller at hun har fått en ny forståelse av meditasjon etter å ha vært på sommerretreat:

Jeg har hatt et bilde eller image av at... meditasjon er når du sitter i ro. $\mathrm{Og}$ det er det, det er ikke noe ann... det finnes ikke andre måter for medita- 
sjon. Så har jeg lært veldig mye omkring det og fått bedre forståelse for hva meditasjon egentlig betyr og at det er en form for consciousness og være bevisst over omgivelsene og lyder, lukter, sanse det som er rundt seg og bare... være der da, og ikke... la tankene vandre et annet sted (Intervju med Stine, 2020).

Stine har hatt et bilde av meditasjon-å sitte i ro-som hun tydeligvis fant igjen i Dharma Mountains annonsering. På retreat har hun likevel blitt sosialisert inn i den brede forståelsen av meditasjon som Vasant Swaha, instruktørene og erfarne deltagere fremmer, nemlig meditasjon som en indre tilstand. I Osho-tradisjonen forstås vipassana, Dynamic og de utallige andre metodene som hjelpemidler, men målet er å gjøre meditasjon til en vedvarende tilstand. Selv om Stine har overtatt idéen om meditasjon som en «form for consciousness», knytter hun seg ikke til idéen om oppvåkning, noe som for hengivne sannyasiner følger av denne forståelsen for meditasjon: Det endelige målet med å meditere er å transcendere seg selv, i Oshos ord å våkne opp til en vedvarende lykksalighet: «Bliss is the goal of sannyas, of being a seeker, and awareness is the path toward it» (OSHO 2013: 8).

Siden Vasant Swaha blir sett på som en som har våknet opp, er både instruktørene og sannyasin-deltagerne, men også Swaha selv, tydelige på å fremheve at meditasjoner er viktige, men at det er satsang som er best i stand til å transformere folk: «Just to be around a mystic can cause a profound change», står det på nettsiden (Vasant Swaha 2021b). I brevene som retreat-deltagerne sender til Swaha og som han leser høyt under satsang, kommer det frem at mange har sterke opplevelser under satsang. I et utpreget religiøst språk skriver en sannyasin:

[A]t the end of every Satsang, every heart can feel a Love so tangible, so real. Like without anybody noticing, he takes us into a new dimension; suddenly everything becomes sacred, holy. The atmosphere becomes pregnant with deep reverence, and every heart whispers a silent prayer of gratitude. In silence He teaches us devotion (Vasant Swaha 2021a).

Både vipassana og Dynamic kan være meningsfylt for en deltager uten noen som helst tilknytning til en guru. Satsang derimot er en praksis som konstruerer og opprettholder mester-disippel-forholdet.

\section{KONKLUSJON}

Det er en utbredt tendens at praksiser som yoga og meditasjon blir løsrevet fra deres kulturelle og religiøse røtter i vestlig, nyåndelig kontekst. Som jeg har vist, er det norske retreatstedet Dharma Mountain et empirisk eksempel som til viss grad går mot denne strømmen. Retreatstedet har ikke bare røtter i sannyas-bevegelsen rundt Osho, men tiltrekker et fellesskap av sannyasiner rundt en levende guru, Vasant Swaha. Likevel slutter 
Dharma Mountain seg i markedsføringen av sine utadrettede arrangementer språklig og estetisk til en popularisert diskurs rundt meditasjon og retreater som nedtoner guruens og sanghaens rolle. Dette viser at mester-disippel-forholdet ikke har blitt like popularisert som meditasjon og fremdeles bekrefter Selbergs observasjon at «[d]et som er velkjent for mange, som for eksempel uttrykk forbundet med alternativ spiritualitet, og som mange påstår nå er del av mainstreamkulturen [...], i mange sammenhenger er omstridt og tvetydig» (Selberg 2009: 42).

De ulike holdningene i samfunnet gjenspeiler seg i at Dharma Mountain har utviklet en slags flertrinnsordning og tilbyr retreater for forskjellige målgrupper. Mens mini-retreatene som «Tilstede» tar utgangspunkt i verdslige problemstillinger og tilbyr en pause fra hverdagen, er retreatene med Vasant Swaha tett knyttet til forestillinger av transcendens og transformasjon. Meditasjon er imidlertid det som gjennomgår og kobler sammen alle trinnene. Dette kan minne om andre guru-bevegelser som demper guruens rolle i visse kulturelle sammenhenger. Inga Bårdsen Tøllefsen viser for den norske grenen av Art of Living, en gruppering grunnlagt i India av den åndelige lederen Sri Sri Ravi Shankar, at guruens rolle nedtones i den norske konteksten til fordel for et fokus på selvutvikling og individuell åndelighet (Bårdsen Tøllefsen 2017: 233-235). Forskjellen er at graderingen på Dharma Mountain ikke gjelder kulturelle forskjeller mellom Norge og India, men ulike grader av innvielse og nærhet til guruen som imøtekommes med ulike eventformater på samme sted.

Med vipassana på nybegynner-helgen «Tilstede» og Dynamic Meditation på sommerretreaten med Vasant Swaha har jeg vist to vidt forskjellige teknikker som begge faller under kategorien «meditasjon». De innrammes på ulike måter, i samsvar med de ulike sosiale situasjonene de utøves i og er med på å konstruere. Vipassana introduseres som en generisk og særlig enkel teknikk, som med sin lave terskel innpasses i smakebitformatet «Tilstede». Selv om praksisens religiøse opphav er svakt markert, har jeg vist at måten den formidles på er forankret i instruktørenes tilhørighet til Swahas tradisjonslinje. Dynamic under retreaten med Swaha, presenteres derimot ikke med et «wellnessspråk», men som en del av en ikke alltid behagelig, men nødvendig selvarbeidsprosess. Metoden krever innsatsvilje og er bundet til Swahas retreat-oppskrift som igjen er avledet av Oshos terapi- og meditasjonsforståelse. Dermed er Dynamic sterkere integrert i Dharma Mountains spesifikke læretradisjon. Praksisen er likevel åpen for forskjellige tolkninger - med eller uten tilknytning til mesteren. Når det gjelder retreatstedets indre kjerne, sanghaen rundt Vasant Swaha, er det likevel satsang som mange opplever som den dypeste og mest virkningsfulle meditasjonen. Her er meditasjonspraksis, mesterens rolle og transcendente målsetninger flettet sammen i gjensidig avhengighet og konstituerer selve guru-institusjonen på Dharma Mountain.

Disse funnene viser til fleksibiliteten av begrepet meditasjon og at den som en slags «flytende signifikant» (Lévi-Strauss [1950] 1987: 63) ikke bare rommer ulike teknikker, men også konseptualiseringer (se Renger og Wulf 2013). Disse kan igjen knyttes til ulike 
motivasjoner—fra selvhjelp til åndelig oppvåkning—og til forskjellige sosialformerfra tjenesteytelse til religiøst fellesskap. Studien min viser at denne spennvidden kan fremmes av de samme aktørene på ett og samme sted. På den ene siden fanges spenninger og paradokser opp av meditasjonsdiskursens romslighet. På den andre siden er meditasjonslandskapet et forhandlingsfelt hvor religiøse og sekulære aktører og organisasjoner plasserer seg og markerer sine grenser.

\section{TAKK TIL}

Tusen takk til redaktøren Margrethe Løøv og to anonyme fagfeller for deres kloke og nyttige innspill til tidligere versjoner av denne artikkelen. Tusen takk også til intervjudeltagerne for deres åpenhet og Dharma Mountain-gruppen som har ikke bare tillatt meg å delta på retreatene, men har også tatt seg tid til å hjelpe meg med å forstå dem bedre.

\section{LITTERATUR}

Braun, Erik. 2013. The Birth of Insight: Meditation, Modern Buddhism, and the Burmese Monk Ledi Sayadaw. Chicago og London: The University of Chicago Press. https://doi.org/10.7208/chicago/9780226000947.001.0001.

Bårdsen Tøllefsen, Inga. 2017. «Hindu-inspired Meditation Movements in Norway: TM, Acem and the Art of Living Foundation». I New Age in Norway, redigert av Ingvild Sælid Gilhus, Siv Ellen Kraft og James R. Lewis, 217-240. Sheffield, UK, Bristol, CT: Equinox. https://doi.org/10.1163/9789004292468_017.

Csordas, Thomas J. 2009. «Introduction. Modalities of Transnational Transcendence». I Transnational Transcendence: Essays on Religion and Globalization, redigert av Thomas J. Csordas, 1-30. Berkeley, CA: University of California Press. https://doi.org/10.1525/9780520943650-002.

Dharma Mountain. 2021a. About us. Tilgjengelig på nett: https://dharmamountain.com/about-usn/ (lest 12. mai 2021).

Dharma Mountain. 2021b. Dynamic saves my life. Tilgjengelig på nett: http://dharmamountain.com/dynamic-saves-my-life/ (lest 12. mai 2021).

Dharma Mountain. 2021c. Tilstede - en helg med skogsbad og meditasjon. Tilgjengelig på nett: http://dharmamountain.com/dharma_activities/tilstede-en-helg-medskogsbad-ogmeditasjon-5/ (lest 12. mai 2021).

Endresen, Cecilie. 2018. «Vin og vinyasa: Yogaturisme på Balkan». Aura: Tidskrift för akademiska studier av nyreligiositet 10: 63-90. https://doi.org/10.31265/aura.524. 
Fonneland, Trude. 2013. «Spiritual Entrepreneurship in a Northern Landscape: Spirituality, Tourism and Politics». Temenos: Nordic Journal of Comparative Religion 48 (2): 155-178. https://doi.org/10.33356/temenos.7510.

Frisk, Liselotte. 2002. «The Satsang Network: A Growing Post-Osho Phenomenon». Nova Religio 6 (1): 64-85. https://doi.org/10.1525/nr.2002.6.1.64.

Frisk, Liselotte. 2016. «Human Potential». I Western Esotericism in Scandinavia, redigert av Henrik Bogdan og Olav Hammer, 195-202. Leiden, Boston: Brill. https://doi.org/10.1163/9789004325968_027.

Frisk, Liselotte, og Peter Åkerbäck. 2013. Den mediterande dalahästen: religion på nya arenor $i$ samtidens Sverige. Stockholm: Dialogos.

Gibsone, Craig, og Jan Martin Bang. 2015. Permaculture: A Spiritual Approach. Forres: Findhorn Press.

Gilbert, Elizabeth. 2006. Eat, Pray, Love: One Woman's Search for Everything Across Italy, India and Indonesia. New York: Viking.

Heelas, Paul. 2009. Spiritualities of Life. Chichester: John Wiley \& Sons.

Heelas, Paul, og Linda Woodhead. 2005. The Spiritual Revolution: Why Religion is Giving Way to Spirituality. Malden, MA: Blackwell.

Heintzmann, Paul. 2012. «Retreat Tourism as a Form of Transformational Tourism». I Transformational Tourism, redigert av Yvette Reisinger, 68-81. Wallingford: CABI. https://doi.org/10.1079/9781780642093.0068.

Honer, Anne, og Ronald Hitzler. 2015. «Life-World-Analytical Ethnography». Journal of Contemporary Ethnography 44 (5): 544-562. https://doi.org/10.1177/0891241615588589.

Höllinger, Franz, og Thomas Tripold. 2012. Ganzheitliches Leben: Das holistische Milieu zwischen neuer Spiritualität und postmoderner Wellness-Kultur. Bielefeld: transcript. https://doi.org/10.1515/transcript.9783839418956.

Jacobs, Bas J.H. 2020. «Getting off the Wheel: A Conceptual History of the New Age Concept of Enlightenment». Numen 67 (4): 373-401. https://doi.org/10.1163/15685276-12341588.

Karapanagiotis, Nicole. 2021. Branding Bhakti: Krishna Consciousness and the Makeover of a Movement. Bloomington: Indiana University Press. https://doi.org/10.2307/j.ctv1d5nm6h. 
Knight, John. 2000. «From Timber to Tourism: Recommoditizing the Japanese Forest». Development and Change 31 (1): 341-359. https://doi.org/10.1111/1467-7660.00157.

Knoblauch, Hubert. 2005. «Focused Ethnography». Forum: Qualitative Social Research 6 (3): Art. 4. https://doi.org/10.17169/fqs-6.3.20.

Knoblauch, Hubert. 2010. «Popular Spirituality». Anthropological Journal of European Cultures 19 (1): 24-39. https://doi.org/10.3167/ajec.2010.190103.

Knoblauch, Hubert. 2013. «Populäre Spiritualität und die Meditation». Paragrana 22 (2): 76-87. https://doi.org/10.1524/para.2013.22.2.76.

Kraft, Siv Ellen. 2007. «Religion and Spirituality in Lonely Planet's India». Religion 37 (3): 230-242. https://doi.org/10.1016/j.religion.2007.07.001.

Lévi-Strauss, Claude. (1950) 1987. Introduction to the Work of Marcel Mauss. Oversatt av Felicity Baker. London: Routledge \& Kegan Paul.

Lucas, Phillip Charles. 2014. «Non-Traditional Modern Advaita Gurus in the West and Their Traditional Modern Advaita Critics». Nova Religio 17 (3): 6-37. https://doi.org/10.1525/nr.2014.17.3.6.

Luckmann, Thomas. 1990. «Shrinking Transcendence, Expanding Religion?» Sociology of Religion 51 (2): 127-138. https://doi.org/10.2307/3710810.

Løøv, Margrethe. 2015. «Acem: Disenchanted Meditation». I Handbook of Nordic New Religions, redigert av James R. Lewis og Inga Bårdsen Tøllefsen, 254-267. Leiden, Boston: Brill.

Nyborg, Line. 2017. «Zen og kunsten å gå på is». Visjon, nr. 1, 6-13.

Olivelle, Patrick. 2018. «Āśrama and Saṃnyāsa». I Brill’s Encyclopedia of Hinduism Online, redigert av Knut A. Jacobsen, Helene Basu, Angelika Malinar og Vasudha Narayanan. http://dx.doi.org/10.1163/2212-5019_BEH_COM_2050030.

OSHO. 1988. «Meditation Is More than Vipassana». I Hari Om Tat Sat: The Divine Sound: That Is the Truth. OSHO Online Library. https://www.osho.com/osho-online-library/osho-talks/vipassana-goenkaheinrich-heine-1ff6050d-671? p=1a92ce4410af95429f36a51e42eb2af8 (lest 3. september 2021).

OSHO. 2000. Autobiography of a Spiritually Incorrect Mystic. New York: St. Martin's Press.

OSHO. 2013. Meditation: The First and Last Freedom. Osho Media International. 
OSHO International Foundation. 2018. A Compendium on OSHO Dynamic Meditation. Pune: Osho Media International.

OSHO International Foundation. 2019a. OSHO Dynamic Meditation. Tilgjengelig på nett: https:/www.oshodynamic.com/osho-frequently-asked-questions.html (lest 6. januar 2021).

OSHO International Foundation. 2019b. OSHO Vipassana Meditation. Tilgjengelig på nett: https://www.osho.com/meditation/osho-active-meditations/oshovipassanameditation (lest 25. mai 2021).

Pagis, Michal. 2019a. Inward: Vipassana Meditation and the Embodiment of the Self. Chicago: The University of Chicago Press. https://doi.org/10.7208/chicago/9780226639413.001.0001.

Pagis, Michal. 2019b. «The Sociology of Meditation». I The Oxford Handbook of Meditation, redigert av Miguel Farias David Brazier og Mansur Lalljee. Oxford University Press. https://doi.org/10.1093/oxfordhb/9780198808640.013.50.

Plank, Katarina, red. 2014. Mindfulness: Tradition, tolkning och tillämpning. Lund: Nordic Academic Press.

Paaske, Christian. 2017. Vasant Swaha-Crazy Wisdom på norsk. Tillgjengelig på nett: https://christianpaaske.wordpress.com/2017/02/16/vasant-swaha-crazy-wisdompanorsk/ (lest 25. mai 2021).

Renger, Almut-Barbara, og Christoph Wulf. 2013. «Meditation als Lebens- und Erfahrungsform». Paragrana 22 (2): 13-25. https://doi.org/10.1524/para.2013.22.2.13.

Repstad, Pål. 2020. Religiøse trender i Norge. Oslo: Universitetsforlaget.

Repstad, Pål, og Irene Trysnes. 2013. Fra forsakelse til feelgood: Musikk, sang og dans i religiøst liv. Oslo: Cappelen Damm Akademisk.

Selberg, Torunn. 2009. «Guruen i granskogen og profet i eget land». Din: Tidsskrift for religion og kultur, nr. 4, 30-44.

Smith, Melanie, og Catherine Kelly. 2006. «Holistic Tourism: Journeys of the Self?» Tourism Recreation Research 31 (1): 15-24. https://doi.org/10.1080/02508281.2006.11081243.

Stausberg, Michael. 2011. Religion and Tourism: Crossroads, Destinations, and Encounters. New York: Routledge. 
Tjellaug, Ane Bamle, og Evelyn Pecori. 2019. «En sjaman går i land». Vårt Land. Tillgjengelig på nett:

https://www.vl.no/reportasje/2019/05/24/en-sjaman-gar-i-land/ (lest 30. mai 2021).

Urban, Hugh B. 2015. Zorba the Buddha: Sex, Spirituality, and Capitalism in the Global Osho Movement. Oakland, CA: University of California Press. https://doi.org/10.1525/9780520961777.

Vasant Swaha. 2021a. Satsang Today: Heart Letter. Tilgjengelig på nett: https://vasantswaha.net/letter/satsang-today/ (lest 25. mai 2021).

Vasant Swaha. 2021b. The Retreat Experience. Tilgjengelig på nett: https://vasantswaha.net/the-retreat-experience/ (lest 27. mai 2021).

Vasant Swaha. 2021c. Who is Swaha? Tilgjengelig på nett: https://vasantswaha.net/who-is-swaha/ (lest 25. mai 2021). 